\title{
Genetic variability in sculpin (genus Cottus) from southern France, with reference to the taxonomic status of an endemic species, C. petiti
}

\author{
R. EPPE*†, H. PERSAT†, D. BEAUDOU \& \& P. BERREBI§ \\ $\dagger$ †SA 5023 Ecologie des Eaux Douces et des Grands Fleuves, Bâtiment 403, Université Claude Bernard Lyon I, \\ 69622 Villeurbanne cedex, France, $\$$ CSP 8ème Délégation, 55 Chemin du Mas de Matour, 34790 Grabels, France \\ and §UPR9060, Laboratoire Génome et Populations, Université Montpellier II, \\ cc063, 34095 Montpellier cedex 05, France
}

\begin{abstract}
The genetic variability of seven populations of Cottus sp. from southern France was analysed using starch-gel electrophoresis. Fourteen enzyme systems were screened revealing seven monomorphic and 12 polymorphic genetic loci. Low within-population allelic variation was observed, with frequent allelic fixations and a maximum of two polymorphic loci per population. By contrast, betweenpopulation variation was high, with several private alleles and a unique genotypic pattern for each population. A neighbour-joining tree clustering Nei distances showed three major clades corresponding to locations in the catchment area of the Loire, the Garonne and the Mediterranean. Within the Mediterranean group, the morphologically distinct population of the Lez river, described as $C$. petiti, was not more differentiated than the other populations on the basis of allozymes.
\end{abstract}

Keywords: allozymes, Cottus, ecological barriers, genetics, isolation processes, systematics.

\section{Introduction}

The common sculpin or river bullhead (Cottus gobio L.) is a small fish living in running waters and along the shore lines of oligotrophic lakes. It is the most widely distributed freshwater species of the Cottidae family in Europe (Koli, 1969a). Its range extends from Scandinavia to central Italy, and from England and Wales as far east as western Siberia (Smyly, 1957). The sculpin is present in almost all drainage basins in France.

Based on the external morphological characters of 17 specimens, a variant of Cottus from southern France was described as a new species by Bacescu \& BacescuMester (1964), C. petiti. This variant is apparently endemic to the headwaters of the Lez, a short river (28.5 km long) flowing to the Mediterranean Sea and mainly fed by resurgent drainage from a karstic plateau north of Montpellier (Fig. 1). Adults of this little known species are small-sized with abundant and unusually large spiniform scales. However, Koli $(1969 a, b)$ considered $C$. petiti to be synonymous with $C$. gobio, because

*Correspondence. E-mail: eppe@biomserv.univ-lyon1.fr (C) 1999 The Genetical Society of Great Britain. the morphological features used to distinguish it are highly variable in common sculpin, especially in the French specimens.

The present study was motivated by this unrecognized $C$. petiti species description, which is still questioned by French ichthyologists. The possible existence of an endemic species raises two questions: (i) does C.petiti actually differ from the other local populations of sculpins (i.e. is it a different species, endemic to the River Lez alone)? and (ii) are there any other major differences between sculpins from the main large drainage basins in France?

Because of the uncertainty of the morphological differentiation, we used genetic markers to describe the differentiation between sculpin populations, including C. petiti.

\section{Materials and methods}

\section{Sampling locations}

Fish were collected by electro-fishing in the CévennesLanguedoc region, in July 1995. Sample locations were chosen within two concentric areas in order to evaluate genetic variability on a local scale and a 


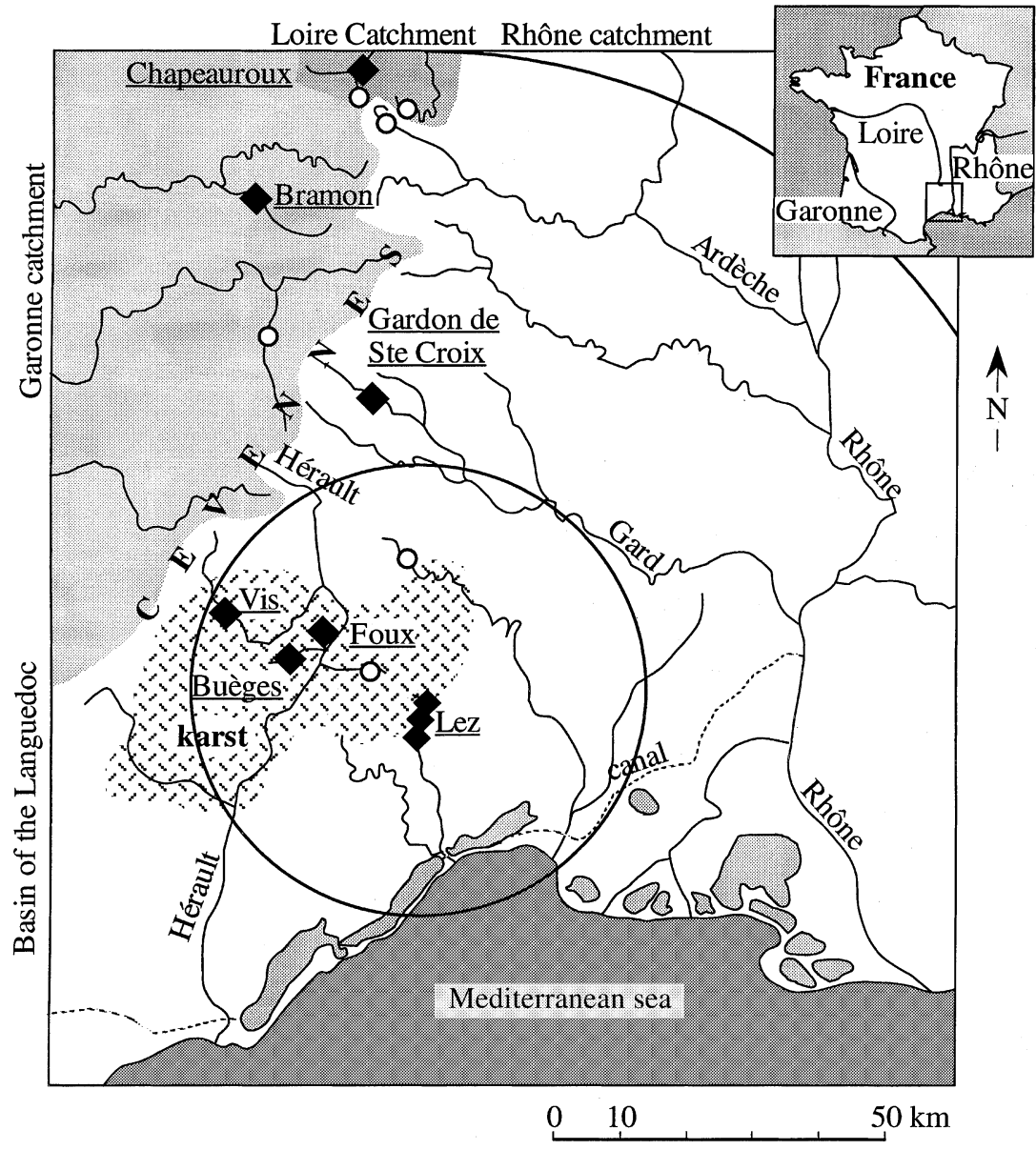

Fig. 1 Map of the sampled stations with sculpins $(\diamond)$ and without $(O)$ in southern France. The sculpin variability was observed in two concentric areas, around the River Lez where the first Cottus petiti had been described. The first area was located in the Languedocian basin, and the larger second contained sites of three major catchments: the Garonne, Loire and Rhône. more regional one (Fig. 1). Sculpin distribution appeared to be discontinuous in the different catchments and rivers, the species being absent in some rivers with apparently appropriate environmental conditions. Among 15 sites sampled only seven provided sculpins: three tributaries of the Hérault (Buèges, Foux de Brissac and Vis) and one tributary in each of the three large peripheral catchments (Loire, Garonne and Rhône) and the Lez.

Summer water temperatures ranged from 13 to $18^{\circ} \mathrm{C}$ dependent on altitude (from 60 to $1140 \mathrm{~m}$ above sea level), and conductivity ranged from 43 to $808 \mu \mathrm{S}$ based on the differing geology (karstic or granitic) of the sites. The amplitude of annual temperature variations is minimal in the karstic resurgences such as the Lez.

None of the individuals collected in the different populations showed the morphology of those from the river Lez, that is very small-sized adults with abundant prickles, and very contrasting male colour patterns. The maximum size of specimens (all adults) collected from the River Lez was $48 \mathrm{~mm}$ total length (TL) (they may exceptionally reach $62 \mathrm{~mm}$ TL; Persat et al., 1996). In contrast, specimens reached $72-81 \mathrm{~mm}$ TL in Hérault tributaries and 90-99 $\mathrm{mm}$ TL in populations farther from the Lez basin.

The area occupied by the Lez sculpin does not extend more than $5 \mathrm{~km}$ downstream from the spring. The population appeared locally quite abundant and was roughly estimated to consist of several thousands of individuals in total.

\section{Genetic analysis}

Genetic data were based on 172 specimens. Samples of liver and skeletal muscle were removed and crushed in an equal volume of $0.12 \%$ Tris- $0.037 \%$ EDTA- $-0.5 \%$ NADP solution. They were then centrifuged at $14300 \mathrm{~g}$ for $40 \mathrm{~min}$ at $4^{\circ} \mathrm{C}$, and stored at $-80^{\circ} \mathrm{C}$.

Extracts were inserted in a horizontal starch gel (12\%) for electrophoresis. The buffer systems used for gels and electrodes were, either pure or diluted: C-Buffer (C: sodium phosphate dibasic $0.89 \%+$ sodium phosphate monobasic $1.56 \%, \mathrm{pH} 6.5$; electrode buffer: 1:10 dilution); MC2-Buffer (morpholine-citric acid buffer: citric acid $1.68 \%+\mathrm{N}$-3-aminopropyl morpholine, $\mathrm{pH}$ 6.1; gel buffer: 1:20 dilution); TPO4-Buffer (Tris-phosphate 
buffer: Tris $1.21 \%+$ sodium phosphate monobasic, $\mathrm{pH}$ 7.4; gel buffer: 1:10 dilution). The staining recipes used were described by Moritz \& Hillis (1990) and Pasteur et al. (1987).

Statistical analysis was carried out with the ECOLOGICAL DATA ANALYSIS software package (ADE 4; Thioulouse et al., 1997), which allowed data for individual allozymes to be viewed on a general factorial plane through a Correspondence Analysis (CA). This ordination technique measures correlations between the presence and absence of alleles within a contingency table. To assess phylogeographical relationships between the different populations, a neighbour-joining cladogram was realized from the Nei (1978) distances with the PHYLIP (Felsenstein, 1989) and TREEVIEW (Page, 1996) software packages.

\section{Results}

Fourteen enzyme systems were analysed, giving 22 loci (Table 1), among which only seven showed no variability across all populations: $A D H^{*}, L D H^{*}, M D H-2^{*}$, $M P I-2^{*}, G P I-2^{*}, P G M^{*}$ and $S O D^{*}$. Fifteen loci appeared polymorphic $(68 \%)$, but three were not reliable enough to be used in the statistical analysis: $M P I-1^{*}, M D H P-2^{*}$ and $M D H P-3^{*}$. The 12 informative loci were: $D D H^{*}, E S T-1^{*}, E S T-2^{*}, E S T-3^{*}, G P I-1^{*}$,
G3PDH-1*, G3PDH-2*,IDDH*,IDH*, MDH-1*, $M D H P-1^{*}$ and $X D H^{*}$ (designation according to Moritz $\&$ Hillis, 1990).

Allozyme data provided a unique genetic pattern for each population. Indeed, allele frequencies (Table 2) showed a much more complex situation than predicted, with the Lez population being neither unique nor more differentiated than several other populations. We observed a globally low within-population variability with frequent allelic fixations, and consistently low observed heterozygozity, from 0.009 in the River Chapeauroux, where 16 out 20 individuals had the same composite genotype, to 0.067 in the River Lez (Table 2). In fact, populations were monomorphic for most of the enzymatic systems considered, and the three more polymorphic populations showed variability for only two out of 19 loci. These populations, Lez, Bramon and Buèges, presented the highest ratio of polymorphic to monomorphic loci (a little less than 0.11).

In contrast to the low within-population variation, variation among-populations was high based on Nei distances and the frequency of private alleles. The Chapeauroux population showed three diagnostic alleles: $D D H^{*}$ variant (92), EST-1*(110) and GPI- $1^{*}(90)$ (Table 2). Bramon showed two other diagnostic alleles, EST-2*(105) and GPI-1*(112). These two populations shared two unique alleles, G3PDH-2*(110) and

Table 1 List of 14 enzyme systems and 22 loci analysed in sculpins. Loci also examined by (1) Brehmer \& Streit (1989), (2) Riffel \& Schreiber (1995) and (3) Hänfling \& Brandl (1998) are indicated

\begin{tabular}{|c|c|c|c|c|c|}
\hline Enzyme & EC code & Locus & Tissue & Alleles & Reference \\
\hline Alchol dehydrogenase & 1.1.1.1 & $A D H^{*}$ & M & 100 & 1,3 \\
\hline Dihydrolipoamide dehydrogenase & 1.8.1.4 & $D D H^{*}$ & $\mathrm{~L}$ & $92 ; 96 ; 100$ & 1 \\
\hline \multirow[t]{3}{*}{ Esterase } & \multirow[t]{3}{*}{ 3.1.1.- } & $E S T-1^{*}$ & M & $100 ; 110$ & \\
\hline & & EST-2* & $\mathrm{L}$ & $100 ; 105$ & \\
\hline & & $E S T-3^{*}$ & $\mathrm{~L}$ & $70 ; 100$ & $1,2,3$ \\
\hline \multirow{2}{*}{ Glycerol-3-phosphate dehydrogenase } & \multirow{2}{*}{ 1.1.1.8 } & $G 3 P D H-1^{*}$ & $\mathrm{M}$ & $60 ; 100$ & \\
\hline & & $G 3 P D H-2^{*}$ & $\mathrm{~L}$ & $100 ; 110$ & $1,2,3$ \\
\hline \multirow[t]{2}{*}{ Glucose-6-phosphate isomerase } & \multirow[t]{2}{*}{ 5.3.1.9 } & $G P I-1^{*}$ & M & $90 ; 100 ; 112$ & \\
\hline & & GPI-2* & $\mathrm{L}$ & 100 & $1,2,3$ \\
\hline L-Iditol dehydrogenase & 1.1.1.14 & $I D D H^{*}$ & $\mathrm{~L}$ & $10 ; 100 ; 110$ & 1,3 \\
\hline Isocitrate dehydrogenase & 1.1.1.42 & $I D H^{*}$ & $\mathrm{~L}$ & $85 ; 100$ & $1,2,3$ \\
\hline Lactate dehydrogenase & 1.1.1.27 & $L D H^{*}$ & M & 100 & $1,2,3$ \\
\hline \multirow[t]{2}{*}{ Malate dehydrogenase } & \multirow[t]{2}{*}{ 1.1.1.37 } & $M D H-1^{*}$ & $\mathrm{~L}$ & $100 ; 130$ & \\
\hline & & $M D H-2 *$ & M & 100 & $1,2,3$ \\
\hline \multirow[t]{3}{*}{ Malic enzyme } & \multirow[t]{3}{*}{1.1 .1 .40} & $M D H P-1^{*}$ & M & $100 ; 110$ & \\
\hline & & $M D H P-2 *$ & $\mathrm{~L}$ & Not reliable & \\
\hline & & $M D H P-3^{*}$ & $\mathrm{M}$ & Not reliable & $1,2,3$ \\
\hline \multirow[t]{2}{*}{ Mannose-6-phosphate isomerase } & \multirow[t]{2}{*}{ 5.3.1.8 } & $M P I-1^{*}$ & $\mathrm{~L}$ & Not reliable & \\
\hline & & $M P I-2^{*}$ & $\mathrm{~L}$ & 100 & $1,2,3$ \\
\hline Phosphoglucomutase & 5.4.2.2 & $P G M^{*}$ & $\mathrm{~L}$ & 100 & $1,2,3$ \\
\hline Superoxide dismutase & 1.15.1.1 & $S O D^{*}$ & $\mathrm{~L}$ & 100 & $1,2,3$ \\
\hline Xanthine dehydrogenase & 1.1.1.204 & $X D H^{*}$ & $\mathrm{~L}$ & $95 ; 100$ & 1 \\
\hline
\end{tabular}

$\mathrm{L}$, liver; $\mathrm{M}$, muscle.

(C) The Genetical Society of Great Britain, Heredity, 83, 533-540. 
Table 2 List of allele frequencies for the common and local alleles of the 12 polymorphic loci analyzed statistically. High between-population variability is highlighted by frequent genetic markers, and each sculpin population is characterized by a unique genetic pattern

\begin{tabular}{|c|c|c|c|c|c|c|c|c|}
\hline \multirow[b]{2}{*}{ Locus } & \multirow[b]{2}{*}{ Allele } & \multicolumn{7}{|c|}{ Populations (Number of specimens) } \\
\hline & & Chap. (20) & Bram. (29) & Foux (27) & Vis (29) & Buèg. (29) & Lez (14) & Gard. (24) \\
\hline \multirow[t]{2}{*}{$E S T-1^{*}$} & 100 & 0 & 1 & 1 & 1 & 1 & 1 & 1 \\
\hline & 110 & 1 & 0 & 0 & 0 & 0 & 0 & 0 \\
\hline \multirow[t]{3}{*}{$G P I-1^{*}$} & $\overline{90}$ & $\overline{\mathbf{1}}$ & 0 & 0 & 0 & 0 & 0 & 0 \\
\hline & $1 \overline{00}$ & $\overline{0}$ & 0 & 1 & 1 & 1 & 1 & 1 \\
\hline & $\underline{112}$ & 0 & $\underline{1}$ & 0 & 0 & 0 & 0 & 0 \\
\hline \multirow[t]{2}{*}{$E S T-2^{*}$} & $\overline{100}$ & 1 & $\overline{0}$ & 1 & 1 & 1 & 1 & 1 \\
\hline & 105 & 0 & 1 & 0 & 0 & 0 & 0 & 0 \\
\hline \multirow[t]{2}{*}{$G 3 P D H-2^{*}$} & $\overline{100}$ & 0 & $\overline{0} .07$ & 1 & 1 & 1 & 1 & 1 \\
\hline & 110 & 1 & 0.93 & 0 & 0 & 0 & 0 & 0 \\
\hline \multirow{3}{*}{$D D H^{*}$} & 92 & 1 & 0 & 0 & 0 & 0 & 0 & 0 \\
\hline & $\overline{96}$ & $\overline{0}$ & 0 & 0 & $\underline{1}$ & 0 & 0 & 0 \\
\hline & $1 \overline{00}$ & 0 & 1 & 1 & $\overline{0}$ & 1 & 1 & 1 \\
\hline \multirow[t]{3}{*}{$I D D H^{*}$} & 10 & 1 & 1 & 0 & 0 & 0 & 0 & 0 \\
\hline & 100 & 0 & 0 & 1 & 1 & 0.88 & 1 & 1 \\
\hline & 110 & 0 & 0 & 0 & 0 & 0.12 & 0 & 0 \\
\hline \multirow[t]{2}{*}{ G3PDH-1* } & 60 & 0.90 & 0 & 0 & 0 & 0 & 0.32 & 0 \\
\hline & 100 & 0.10 & 1 & 1 & 1 & 1 & 0.68 & 1 \\
\hline \multirow[t]{2}{*}{$X D H^{*}$} & 95 & 1 & 0 & 0 & 1 & 1 & 0 & 0 \\
\hline & 100 & 0 & 1 & 1 & 0 & 0 & 1 & 1 \\
\hline \multirow[t]{2}{*}{$M D H-I^{*}$} & 100 & 1 & 0.90 & 0.78 & 1 & 0.86 & 1 & 1 \\
\hline & 130 & 0 & 0.10 & 0.22 & 0 & 0.14 & 0 & 0 \\
\hline \multirow[t]{2}{*}{$I D H^{*}$} & 85 & 0 & 0 & 0 & 0.60 & 0 & 0.86 & 0 \\
\hline & 100 & 1 & 1 & 1 & 0.40 & 1 & 0.14 & 1 \\
\hline \multirow[t]{2}{*}{$E S T-3^{*}$} & $\underline{70}$ & 0 & 0 & $\underline{1}$ & $\underline{1}$ & $\underline{1}$ & 0 & 0 \\
\hline & $1 \overline{00}$ & 1 & 1 & $\overline{0}$ & $\overline{0}$ & $\overline{0}$ & 1 & 1 \\
\hline \multirow[t]{2}{*}{$M H D P-1^{*}$} & 100 & 1 & 1 & 0 & 0 & 0 & 1 & 0.54 \\
\hline & 110 & 0 & 0 & 1 & 1 & 1 & 0 & 0.46 \\
\hline Polymorphism 99\% & & 0.053 & 0.105 & 0.053 & 0.053 & 0.105 & 0.105 & 0.053 \\
\hline Observed heterozygosity & & 0.009 & 0.016 & 0.018 & 0.025 & 0.027 & 0.067 & 0.026 \\
\hline
\end{tabular}

Chap., Chapeauroux; Bram., Bramon; Buèg., Buèges; Gard., Gardon.

$I D D H^{*}(10)$, which characterized these 'Atlantic populations'.

One rare allele, G3PDH-1*(60), was found in geographically disjunct populations (the Lez and Chapeauroux rivers). Several different buffering conditions were used in an attempt to resolve potential differences in this allele, but none was found.

Among the 'Mediterranean populations', the Gardon population was fixed for the most common allele at each locus except $M D H P-I^{*}$. The allele $M D H P$ $1^{*}(110)$, found at intermediate frequency in the Gardon population, is one of two diagnostic alleles (together with $E S T-3^{*}[70]$ ) for the three populations of the Hérault tributaries. Despite the strong clustering of the Hérault populations, two alleles, $D D H^{*}(96)$ and $I D D H^{*}(110)$, were nonetheless distinct in single tributaries demonstrating little or no gene flow within the catchment (Table 2). The lack of the allele $X D H^{*}(95)$ in the Foux population further demonstrates the fine-scale genetic heterogeneity in the Hérault catchment. Excepting the common alleles, the only convergence between this basin and the River Lez was the presence of the allele $I D H^{*}(85)$ in both the Lez and Vis.

The Lez and Gardon populations are rather similar (Table 2), with no fixed differences. They showed fixation for nearly all common alleles. The other populations showed more alleles different from common ones: seven for the Chapeauroux population, five for the Bramon, Vis and Buèges, and only three for the Foux de Brissac population (of which two were characteristic of the Hérault catchment).

Although some geographical patterns in allele frequencies emerge, important exceptions exist such as

(c) The Genetical Society of Great Britain, Heredity, 83, 533-540. 


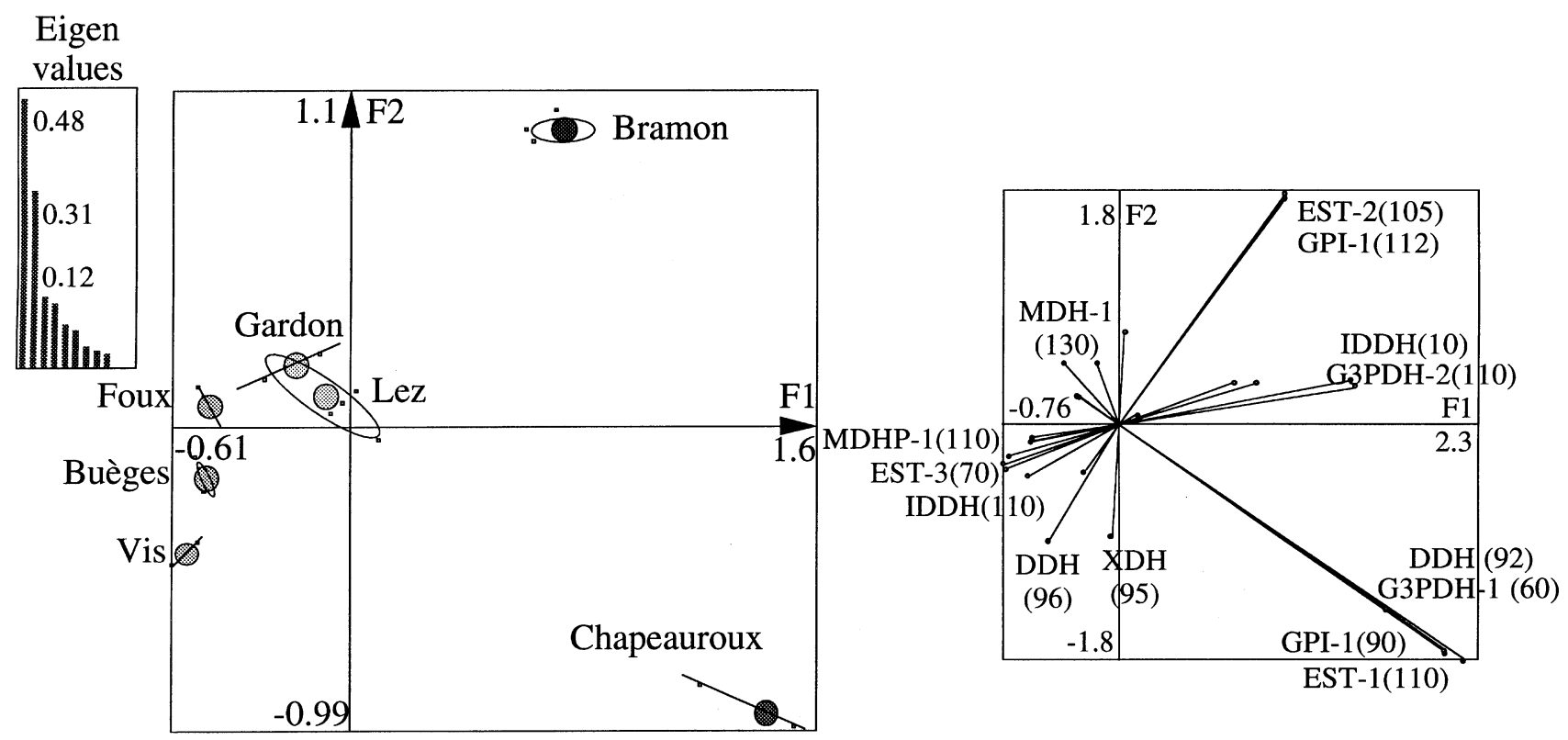

Fig. 2 Factorial maps showing the clear separation by Correspondence Analysis of the two 'Atlantic' populations of sculpins from the 'Mediterranean' ones. The larger graph depicts individual populations on a multifactorial plane, and the smaller one shows the contribution of individual alleles to the given factors.

G3PDH-1*(60) in the Lez and Chapeauroux (where we assume homology of alleles based on parsimony).

The results of the Correspondence Analysis focus on the relative contributions of each allele in distinguishing between populations (Fig. 2). The populations are represented by their barycentres and an ellipse containing $95 \%$ of the genotype plots. The ellipse is reduced to a line when only one locus is polymorphic. The first factor highlights the relative segregation between the Mediterranean populations and the two Atlantic ones, Chapeauroux and Bramon. The second factor mainly separates these last two populations in spite of two common alleles. The analysis separates the Lez and Gardon populations from those of the Hérault tributaries (Fig. 2). No overlap appears between the three populations of the Hérault catchment. This heterogeneity is supported by the Nei distances, with a maximal value of 0.139 for the Vis/Foux de Brissac distance (Table 3).

Table 3 Nei distances for each pair of sculpin populations

\begin{tabular}{lccccccc}
\hline & Chapeauroux & \multicolumn{3}{c}{ Bramon Buèges } & Foux & Vis & Gardon \\
\hline Lez & 0.413 & 0.236 & 0.227 & 0.162 & 0.254 & 0.051 \\
Gardon & 0.416 & 0.200 & 0.134 & 0.075 & 0.220 & \\
Vis & 0.515 & 0.524 & 0.078 & 0.139 & & \\
Foux & 0.577 & 0.326 & 0.056 & & & \\
Buèges & 0.480 & 0.401 & & & & \\
Bramon & 0.384 & & & & & \\
\hline
\end{tabular}

The neighbour-joining cladogram built on betweenpopulation Nei distances appeared congruent with geographical locations (Fig. 3). Three principal entities were resolved with high genetic divergence between them: on one hand, the distant Atlantic populations (0.384) with the Loire and the Garonne catchments, and on the other hand, the Mediterranean basin with five relatively proximate populations.

The three populations of the Hérault tributaries constituted an infra-group within the Mediterranean group. Despite their relatively large geographical separation (Fig. 1), the Lez and Gardon populations appeared to be as genetically proximate $(0.051)$ as the Foux-Buèges pair (0.056) (Table 3).

Overall, Nei distances were relatively high with an average distance between all the pairs reaching 0.28 , which is above the 0.2 units often considered as an interspecific distance (Zimmerman \& Wooten, 1981; Thorpe, 1982; Andoh \& Goto, 1988; Hänfling \& Brandl, 1998).

\section{Discussion}

\section{Allozymic knowledge of the genus Cottus}

Studies on river sculpins have been performed in Germany, USA and Japan.

In Germany, among five populations of the single Kinzig river system (Main catchment), Brehmer \& Streit (1989) observed only $10 \%$ polymorphic loci (three out of 31 ) and the average heterozygosity did not exceed 0.006 .

(C) The Genetical Society of Great Britain, Heredity, 83, 533-540. 


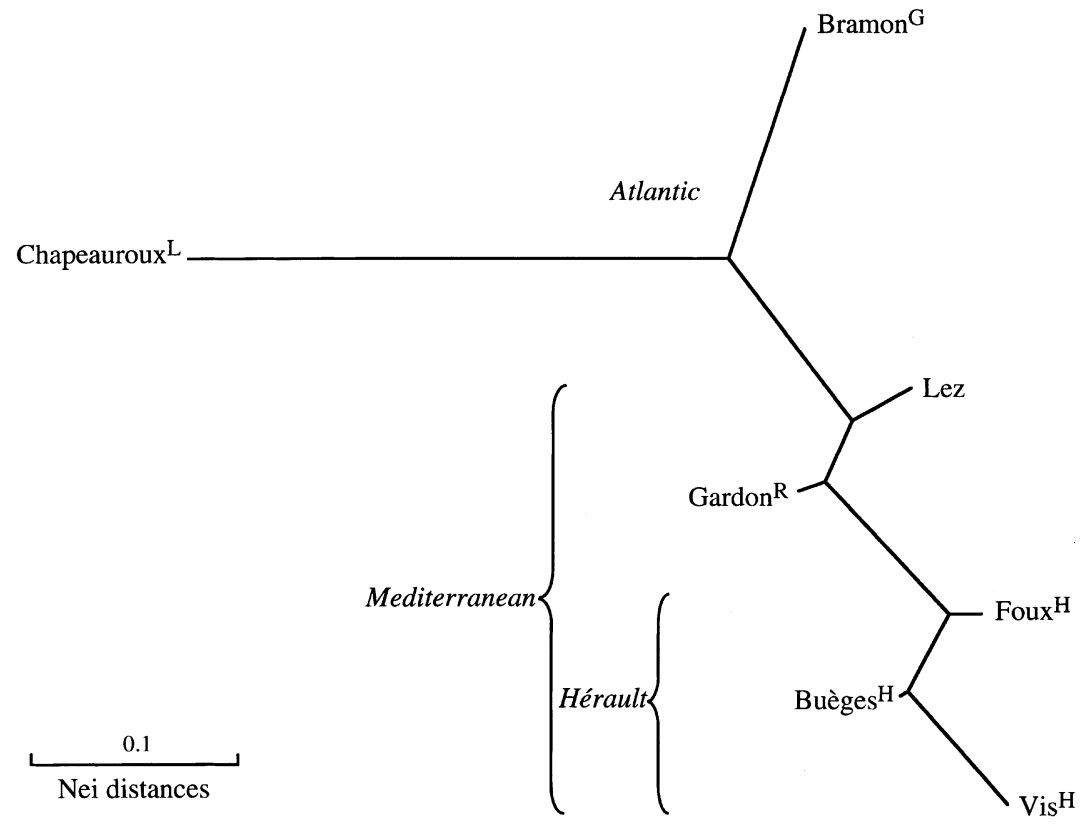

Fig. 3 The Neighbour-joining cladogram clustering Nei (1978) distances between sculpin populations. Three main entities are separated by high genetic distances: the two distinct 'Atlantic' populations (Garonne G and Loire $\mathrm{L}$ catchments) and a meridional group consisting of the River Lez, the River Gardon (Rhône catchment R) and the Hérault tributaries $\mathrm{H}$.
Across a much larger sampling area, Riffel \& Schreiber (1995) observed $40 \%$ polymorphic loci (12 out of 29) among 25 populations from the Danube, Rhine and Rhône catchments. However, the alleles were generally fixed in at least 18 of these populations, and average polymorphism and heterozygosity did not exceed 0.07 and 0.017 , respectively. The genetic distances between streams within drainages were low (means of 0.026 and 0.005 , respectively, for the Danube and Neckar basins) and relative genetic homogeneity was observed between the Danubian and Neckarian drainages.

In the Rhine, Danube and Elbe catchments, Hänfling \& Brandl (1998) observed 65\% polymorphic loci (20 out of 31) among 16 populations. Only one locus showed differential allelic fixation between the Danube and Elbe catchments, but three loci between the Rhine and Elbe catchments, and five between the Rhine and Danube catchments. An average distance of 0.24 between populations of the Rhine and Danube-Elbe catchments led Hänfling \& Brandl (1998) to assume the existence of two differentiated taxa. This distinction was also supported by differences in heterozygosity (between 0.008 and 0.099) as well as morphological measures such as body length, head length, distance between eyes and fin ray counts.

In populations of mottled sculpin, C. bairdi from drainages in Maryland and Pennsylvania, USA, 13 out of 32 loci $(40 \%)$ appeared polymorphic, but for seven of them the common allele had a frequency $>95 \%$ (Howard \& Morgan, 1993). Distances as large as 0.098 separated populations of the Youghiogheny and Potomac river drainages.
In the Flathead river system (Montana), the mean distances observed in populations of C. confusus and C. cognatus were, respectively, 0.01 and 0.08 , with two and four polymorphic loci (Zimmerman \& Wooten, 1981). With two other loci separating these sympatric species by differential allelic fixation, the interspecific mean distance reached 0.20 .

Lastly, in landlocked sculpin populations of the Hokkaido island (Japan), Goto \& Andoh (1990) observed, respectively, $15 \%$ and $25 \%$ polymorphic loci (three and five out of 20) in C. amblystomopsis and in C. nozawae. The alleles were always fixed or nearly fixed in each population. The average distance between these two river sculpin species, until recently considered as two ecomorphs of the same species, reached $0.175(0.22$ units in an earlier study; Andoh \& Goto, 1988). This between-species distance was significantly higher than intraspecific distances found between populations of amphidromous (C. amblystomopsis) (0.002) and fluvial populations (C. nozawae) (0.029).

Finally, the within-population variation that we observed in the French sculpins is similar to that reported in most of the populations in the Danube, Elbe, Neckar, Rhine and Rhône basins. The percentage polymorphic loci and observed heterozygosity were, respectively, $0.075 \pm 0.028(\mathrm{SE})$ and $0.020 \pm 0.007$ in all but the Lez populations. With a relatively high observed heterozygosity (0.067), the Lez population constituted a special case, comparable with those observed in one Neckar population (Riffel \& Schreiber, 1995) and in some Rhine populations (Hänfling \& Brandl, 1998). 


\section{Speculation on population history}

A frequent explanation for such allozymic patterns is a series of drift events resulting from multiple population 'bottlenecks' or 'founder effects' stemming from an ancestral population with high allelic diversity. Colonization and dispersal events could have been followed by 'secondary' geographical isolations. In sculpin, such isolation might have been reinforced by the sedentary nature and low effective population sizes characteristic of this group. Naturally, these factors may have affected allelic diversity in each population, in unique, or independent ways.

Although this hypothesis can explain most of our genetic observations, no trace of a supposed 'original superpopulation' presenting sufficient allelic variability has, as yet, been detected (Brehmer \& Streit, 1989; Riffel \& Schreiber, 1995; Hänfling \& Brandl, 1998). Thus, the existence of such a highly polymorphic population is speculative.

The congruence between the cladogram and geography, however, allows some hypotheses concerning colonization patterns of the sculpin. The Nei distances calculated between the examined populations suggest a chronology of historical segregations between populations of different catchments and rivers. The Atlantic populations of the Loire and Garonne catchments would have first been separated from those of the Mediterranean watershed, and then one from the other. The Mediterranean ones would have more recently been separated into two groups, those of the Hérault catchment, and those of the Lez and Gardon, which we can pool into a Rhône type. Indeed, this scheme would be quite plausible, based on the data, with the exception of the distribution of $G 3 P D H-1 *(60)$ allele.

Although our allozyme data cannot be used to estimate times of divergence, palaeogeographical knowledge can provide some historical reference; for instance, similarities between populations of the Lez and a tributary of the Rhône like the Gardon de Sainte Croix make sense in light of the fact that during the Riss icecap maximum, 30000 years ago, the Rhône estuary was situated further westwards along the Languedoc coast (Persat \& Berrebi, 1990). Because of the proximity of these rivers, and the thermal conditions of this period, we can presume a connection of the two water courses at this time. This connection would have allowed colonization of the River Lez and the relative homogenization of its gene pool with that of populations found in the Gardon.

Concerning divergence times for the three main lineages identified in our study, we can refer to the data from Central Europe. From the differential allelic fixations of three or more loci and significant genetic distances (nearly 0.22), Riffel \& Schreiber (1995) hypothesized an anteglacial divergence between the Rhône and Danube or Neckar catchments. Hänfling \& Brandl (1998) suggested some palaeogeographical events at the Pliocene-Pleistocene boundary to explain the separation of the sculpin populations of the Rhine and Elbe systems. If all these authors are correct, and considering the larger genetic distances observed in France, the divergence events involved here must be more ancient, having occurred during the Pliocene, i.e. 2-5 Ma.

\section{Sedentariness and dominance: behavioural factors of reproductive isolation}

High population structuring of sculpin is further explained by the sculpin's sedentary and territorial behaviour coupled with a strong homing instinct. Agonistic interactions between males constrain their movements in the field (Downhower \& Brown, 1979). The home range does not exceed 5-15 m. Thus, even relatively proximate populations can act as truly isolated demes (Downhower et al., 1990). Moreover, several observations have highlighted unequal male contributions to reproduction (Downhower \& Brown, 1979). Indeed, females selectively mate with the largest males (Bisazza \& Marconato, 1988), who provide the best protection of the eggs (Brown, 1981), and prefer those already guarding eggs (Marconato \& Bisazza, 1986). This process may reduce the number of males involved in reproduction, thus lowering the effective population size.

Additional variation in life-history strategies and agestructure, often through adaptations to variable environmental constraints (Craig \& Wells, 1976; Fox, 1978), can further influence the genetic structure of Cottus species. Thus, in contrast with the annual-laying common sculpin model, Lez sculpin females are regularly able to spawn at less than one monthly intervals throughout the year.

\section{Conclusion}

Our results confirm that the common sculpin is one of the most highly structured freshwater fish species. They suggest the existence of several close-neighbour species or subspecies of a C. gobio group, isolated by both geographical and ecological factors. This supports the view of Koli (1969a) that 'the geographical variation in some characters of C. gobio is basically subspecific in nature'. Among the seven sampled populations, the Nei distances obtained between the Loire and Garonne, between the Loire and Mediterranean, and between the Garonne and Mediterranean, could be used to characterize three different subspecies or species. In the Mediterranean group, $C$. petiti appeared more differentiated based on 
morphological and ecological factors than on genetic ones.

Concerning sculpin systematics, allozyme data generally appear to be more sensitive than morphology in detecting population structure. Nevertheless, the high among-population variability, with rare nonfixed alleles, limits conclusions concerning gene flow between populations. Like the sculpin population distribution, the geographical distribution of most alleles is discontinuous, and it is still difficult to establish a gradient of genetic differentiation among whole populations. The sampling of other French rivers from the Mediterrranean, Atlantic and North Sea catchments will be necessary to describe genetic variation in this region more accurately.

\section{Acknowledgements}

We thank the French Ministry of Environment which has partly funded this study, the Délégation Régionale du Conseil Supérieur de la Pêche de Montpellier for its collaboration in fish collecting, and Dr S. Weiss, who kindly reviewed the first draft of this manuscript.

\section{References}

ANDOH, T. AND GOTO, A. 1988. Biochemical evidence for reproductive isolation between sympatric populations of Cottus amblystomopsis and C. nozawae. Jap. J. Ichthyol., 35, 176-183.

BACESCU, M. AND BACESCU-MeSTER, L. 1964. Cottus petiti sp. n., un chabot nouveau récolté en France. Considérations zoogéographiques et données comparatives sur d'autres Cottus d'Europe. Vie et Milieu, 17 (Suppl.), 431-446.

BISAZZA, A. AND MARCONATO, A. 1988. Female mate choice, male-male competition and parental care in the river bullhead, Cottus gobio L. (Pisces, Cottidae). Anim. Behav., 36, 1352-1360.

BREHMER, B. AND STREIT, B. 1989. Genetische Variation bei der Groppe (Cottus gobio L.). Fischökologie, 1, 1-14.

BROWN, L. 1981. Patterns of female choice in Mottled Sculpin (Cottidae, Teleostei). Anim. Behav., 29, 375-382.

CRAIG, P. AND WELls, J. 1976. Life history notes for a population of Slimy Sculpin Cottus cognatus in an Alaskan Arctic stream. J. Fish. Res. Board Can., 33, 1639-1642.

DOWNHOWER, J. AND BROWN, L. 1979. Seasonal changes in the social structure of a mottled sculpin (Cottus bairdi) population. Anim. Behav., 27, 451-458.

DOWNHOWER, J., LEJEUNE, P., GAUDIN, P. AND BROWN, L. 1990. Movements of the Chabot (Cottus gobio) in a small stream. Pol. Arch. Hydrobiol., 37, 119-126.

FELSENSTEIN, J. 1989. PHYLIP-Phylogeny Inference Package (version 3.2). Cladistics, 5, 164-166.

FOX, P. 1978. Preliminary observations on different reproduction strategies in the bullhead (Cottus gobio L.) in northern and southern England. J. Fish Biol., 12, 5-11.
GOTO, A. AND ANDOH, T. 1990. Genetic divergence between the sibling species of river-sculpin, Cottus amblystomopsis and C. nozawae, with special reference to speciation. Environ. Biol. Fish., 28, 257-270.

HÄNFLING, B. AND BRANDL, R. 1998. Genetic differentiation of the bullhead Cottus gobio L. across the watersheds in Central Europe: evidence for two taxa. Heredity, 80, 110117.

HOWARD, J. AND MORGAN, R. 1993. Allozyme variation in the mottled sculpin (Cottus bairdi): a test of stream capture hypotheses. Copeia, 3, 870-875.

KOLI, L. 1969a. Geographical variation of Cottus gobio L. (Pisces, Cottidae) in Northern Europe. Ann. Zoo. Fenn., 6, 353-390.

KOLI, L. 1969b. The spiniform armature of some Palearctic freshwater species of the family Cottidae (Pisces). Ann. Zoo. Fenn., 6, 428-430.

MARCONATO, A. AND BISAZZA, A. 1986. Males whose nests contain eggs are preferred by female Cottus gobio L. (Pisces, Cottidae). Anim. Behav., 34, 1580-1582.

MORITZ, C. AND HILlis, D. 1990. Molecular Systematics: Context and Controversies. Sinauer Associates, Sunderland, MA.

NEI, M. 1978. Estimation of average heterozygosity and genetic distances from a small number of individuals. Genetics, 89, 583-590.

PAGE, R. 1996. TREEVIEW: an application to display phylogenetic trees on personal computers. Comput. Appl. Biosci., 12, 357-358.

PASTEUR, N., PASTEUR, G., BONHOMMe, F., CATALAN, J. AND BRITTION-DAVIDIAN, J. 1987. Manuel Technique de Génétique par Electrophorèse des Protéines. Technique et documentation (Lavoisier), Paris.

PERSAT, H. AND BERREBI, P. 1990. Relative ages of present populations of Barbus barbus and Barbus meridionalis (Cyprinidae) in southern France: preliminary considerations. Aquat. Living Resour., 3, 253-263.

PERSAT, H., BEAUDOU, D. AND FREYHOF, J. 1996. The sculpin of the Lez spring (South France), Cottus petiti (Bacescu and Bacescu-Mester, 1964), one of the most threatened fish species in Europe. In: Kirchhofer, A. and Hefti, D. (eds) Conservation of Endangered Freshwater Fish in Europe, pp. 321-328. Birkhäuser, Basel.

RIFFEL, M. AND SCHREIBER, A. 1995. Coarse-grained population structure in Central European sculpin (Cottus gobio L.): secondary contact or ongoing genetic drift? J. Zoo. Syst. Evol. Research, 33, 173-184.

SMYLY, w. 1957. The life-history of the bullhead or Miller's thumb (Cottus gobio L.). Proc. Zool. Soc. Lond., 128, 431453.

THIOUlouse, J., DOLEDEC, S., CHESSEl, D. AND OLIVIER, J. 1997. ADE-4: a multivariate analysis and graphical display software. Stat. Comput., 7, 75-83.

THORPE, J. 1982. The molecular clock hypothesis: Biochemical evaluation, genetic differentiation and systematics. Ann. Rev. Ecol. Syst., 13, 139-168.

ZIMMERMAN, E. AND WOOTEN, M. 1981. Allozymic variation and natural hybridization in sculpins, Cottus confusus and Cottus cognatus. Biochem. Syst. Ecol., 9, 341-346. 